\title{
Increasing Al-pair abundance in SSZ-13 zeolite via zeolite synthesis in the presence of alkaline earth metal hydroxide produces hydro- thermally stable Cobalt and Pd-SSZ-13 materials for pollutant abatement applications
}

Konstantin Khivantsev ${ }^{1 *} \uparrow$, Miroslaw A. Derewinski ${ }^{1,2^{*}} \uparrow$, Nicholas R. Jaegers ${ }^{1}$, Daria Boglaienko ${ }^{1}, X^{-}$ vier Isidro Pereira Hernandez ${ }^{1}$, Carolyn Pearce ${ }^{1}$, Yong Wang ${ }^{1,3}$ and Janos Szanyi ${ }^{*} \dagger$

${ }^{1}$ Pacific Northwest National Laboratory Richland, WA 99352 USA

${ }^{2}$ J. Haber Institute of Catalysis and Surface Chemistry, Polish Academy of Sciences, Krakow 30-239, Poland

${ }^{3}$ The Gene and Linda Voiland School of Chemical Engineering and Bioengineering, Washington State University

Pullman, WA 99164-6515

We dedicate this study to Mirek Derewinski on occasion of his $70^{\text {th }}$ birthday and remarkable contributions to the field of zeolite synthesis, chemistry, and reactivity!

*corresponding authors: MAD, KK, JSz

$\dagger$ these authors contributed equally: KK, MAD, JSz

\begin{abstract}
We show that replacing alkaline $(\mathrm{NaOH})$ for alkaline-earth metal $\left(\mathrm{Sr}(\mathrm{OH})_{2}\right.$ as an example) in the synthesis of SSZ-13 zeolite with $\mathrm{Si} / \mathrm{Al} \sim 10$ produces SSZ-13 zeolite material with novel, advantageous properties. Its $\mathrm{NH}_{4}$-form ion-exchanges higher amount of Co(II) ions than the conventional one: this is the consequence of increased number of Al pairs in the structure induced by the $+2 \mathrm{charge}$ of $\mathrm{Sr}$ (II) cations in the synthesis gel that force two charge-compensating $\mathrm{AlO}_{4}^{-}$motives to be closer together. We characterize the +2 state of $\mathrm{Co}$ (II) ions in these materials with infra-red spectroscopy and XANES measurements. They can be used for NOx pollutant adsorption from ambient air: the ones derived from SSZ-13 with higher Al pair content contain more cobalt(II) and thus, perform better as ambient-air NOx adsorbers before reaching full saturation capacity. Notably, Co(II)/SSZ-13 material with increased number of Al pairs is significantly more hydrothermally stable than its $\mathrm{NaOH}$-derived analogue. Loading $1.7 \mathrm{wt} \% \mathrm{Pd}$ into Co-SSZ-13 synthesized in the presence of Sr(II) produces an active passive NOx adsorber (PNA) material that can be used for NOx adsorption from simulated diesel engine exhaust. The critical issue for these applications is hydrothermal stability of Pd-zeolites. Pd/SSZ-13 synthesized in $\mathrm{NaOH}$ media loses most of its PNA capacity after $\sim 800{ }^{\circ} \mathrm{C}$ hydrothermal aging in the flow of air and steam (10 hours in $10 \% \mathrm{H}_{2} \mathrm{O} /$ air flow). The $1.7 \mathrm{wt} \% \mathrm{Pd} / \mathrm{Co} / \mathrm{SSZ}-13$ material with $\mathrm{Si} / \mathrm{Al} \sim 10 \mathrm{does}$ not lose its PNA capacity after extremely harsh aging at 850 and $900{ }^{\circ} \mathrm{C}\left(10\right.$ hours in $10 \% \mathrm{H}_{2} \mathrm{O} /$ Air flow $)$ and loses only $~ 55 \%$ capacity after hydrothermal aging at $930^{\circ} \mathrm{C}$. It shows considerably enhanced stability compared with previous record for Pd/FER, Pd/SSZ-39 and Pd/BEA materials that could survive hydrothermal aging no higher than $820^{\circ} \mathrm{C}$. We herein reveal a new, simple, and scalable strategy for making remarkably (hydro)thermally stable metal-zeolite materials/catalysts with a number of useful applications.
\end{abstract}

Within the last decade, Metal/zeolites system became the front-liners of environmental catalysis [1,2]. These materials/catalysts have allowed to tackle the most challenging environmental problems caused by pollutant emitted by the vehicles [1-7]. More specifically, nitric oxide is a free-radical harmful pollutant, even more dangerous than carbon monoxide (CO). Nearly 55\% of the global NOx emissions come from vehicles [1,8-10]. $\mathrm{Cu}$ /zeolite materials have been successfully commercialized to scrub NOx and turn it into environmentally clean dinitrogen in diesel vehicles [1-7]. Sacrificial ammonia reductant is used, and this catalytic reaction is effective at temperatures starting $180{ }^{\circ} \mathrm{C}$ with state-of-the-art catalyst formulations. Significant advances have been achieved in understanding the fundamental nature of catalytic SCR reaction on $\mathrm{Cu} / \mathrm{SSZ}-13$ and $\mathrm{Cu} / \mathrm{BEA}$ zeolitic systems [1-7,11-18]. Although $\mathrm{Cu} / \mathrm{SSZ}-13$ catalysts show excellent activity above $200^{\circ} \mathrm{C}$, no catalysts were shown to be active at lower temperatures. Only recently have we discovered that $\mathrm{NO}^{+}$ions in zeolites (formed via $\mathrm{NO}+\mathrm{O}_{2}$ reaction) catalyze direct reduction of $\mathrm{NO}^{+}$with $\mathrm{NH}_{3}$ to nitrogen at room temperature and below [18]. The process can be run catalytically when some $\mathrm{NH}_{3}$ can desorb from zeolite [18]. However, higher temperatures require $\mathrm{Cu}(\mathrm{II})$ ions presence due to, in part, ability to form $\mathrm{Cu}(\mathrm{I})---\mathrm{NO}^{+}$site by direct $\mathrm{Cu}(\mathrm{II})$ reduction with free-radical NO. Emissions 
during vehicle cold start, however, remain a challenge. To circumvent this challenge, $\mathrm{Pd} /$ zeolite materials (passive NOx adsorbers) have been introduced industrially that adsorb NO strongly as $\mathrm{Pd}(\mathrm{II})-\mathrm{NO}, \mathrm{Pd}(\mathrm{I})-$ $\mathrm{NO}, \mathrm{Pd}(\mathrm{II})(\mathrm{OH})(\mathrm{NO})$ and $\mathrm{Pd}(\mathrm{II})(\mathrm{NO})(\mathrm{CO})$ complexes (depending on Pd speciation in zeolites) at low temperatures $\left(80-130{ }^{\circ} \mathrm{C}\right)$ during cold start and then release them at higher temperatures $\left(>170-180{ }^{\circ} \mathrm{C}\right)$ when downstream SCR catalysts become very active [19-35]. The main challenge for application of Metal/zeolite materials for industrial vehicle use has always been their hydrothermal stability. They may be exposed in vehicles to harsh steam treatment (during diesel particular filter regeneration, for example) [19-33]. In general, it is desirable to develop materials that can survive hydrothermal aging at temperatures as harsh as $800{ }^{\circ} \mathrm{C}$ and higher. For passive NOx adsorbers, the highest known survival temperatures are $750-820^{\circ} \mathrm{C}$ [19-33]. For example, we have been able to engineer Pd/BEA crystals that can survive 750 ${ }^{\circ} \mathrm{C}$ hydrothermal treatment without any deterioration [21]. For SSZ-13 materials prepared via regular method (in the presence of $\mathrm{NaOH}$ and $\mathrm{N}$ (adamantyl) structure-directing agents) $750{ }^{\circ} \mathrm{C}$ hydrothermal aging (HTA) already leads to erosion of some $\mathrm{Pd}(\mathrm{II})$ ions and their transformation into nanoparticles on the external zeolite surface, likely through $\mathrm{Pd}$ aluminate and $\mathrm{Pd}_{\mathrm{x}}(\mathrm{OH})_{\mathrm{y}}$ species formation in the presence of water (with simultaneous framework dealumination) [25-27, 34, 35]. Therefore, there is an urgent need to develop hydrothermally stable SSZ-13 materials. It is important to note that the Si/Al ratio of zeolite plays an important part in stability: the higher the $\mathrm{Si} / \mathrm{Al}$ ratio, the more hydrophobic the inner pore of zeolite is (considering no significant amount of other defects are present), and the more resistant to steam HTA treatment it is $[21,27]$. However, as we convincingly showed recently, with increase of Si/Al ration from 6 to 10-12 to 20-30, hydrophobicity of the pores leads to exclusion of atomically dispersed M(II) species and formation of MOx nanoparticles on the external surface (due to hydrophobicity of the pore and the inability of the aqua hydroxo complexes of metal to get "inside") [20,22,25]. Furthermore, Pd distribution changes with increase of $\mathrm{Si} / \mathrm{Al}$ ratio: for $\mathrm{SSZ}-13$ with $\mathrm{Si} / \mathrm{Al}$ ratio 6, Pd was almost completely atomically dispersed and present exclusively as $\mathrm{Pd}(\mathrm{II})$ ions held by proximal $\mathrm{AlO}_{4}{ }^{-}$pairs $[20,22]$. For sample with $\mathrm{Si} / \mathrm{Al}$ ratio $10-12$, around $\sim 80-90 \% \mathrm{Pd}$ was atomically dispersed and present as a mixture of $\mathrm{Pd}(\mathrm{II})$ and $\mathrm{Pd}(\mathrm{II})-\mathrm{OH}$ species [20,22]. For sample with higher $\mathrm{Si} / \mathrm{Al}$ ratio much less $(<30 \%)$ of $\mathrm{Pd}$ was atomically dispersed and present exclusively as $\mathrm{Pd}(\mathrm{II})-\mathrm{OH}$ species [20,22]. $\mathrm{Pd}(\mathrm{II})$ ions are more active and stable towards PNA. Thus, we chose to focus on the zeolite with $\mathrm{Si} / \mathrm{Al} \sim 10$ (providing higher hydrothermal stability than $\mathrm{Si} / \mathrm{Al}$ 6) that can still accommodate most of $\mathrm{Pd}$ as atomically dispersed species. Furthermore, for the sample with $\mathrm{Si} / \mathrm{Al} \sim 5-6$ most of $\mathrm{Al}$ would be present as proximal pairs, most likely, irrespective of synthesis conditions due to significant abundance of $\mathrm{Al}$. However, for higher $\mathrm{Si} / \mathrm{Al}$ ratios statistically speaking less Al sites will be proximal and thus it would be harder to create the desired M(II) 
sites. We hypothesized that we could create more Al paired sites by introducing alkaline earth metals (such as $\mathrm{Sr}(\mathrm{OH})_{2}$ or $\mathrm{Ba}(\mathrm{OH})_{2}$ ) in the synthesis gel instead of typically used $\mathrm{NaOH}$. We focused on $\mathrm{Sr}$ specifically rather than $\mathrm{Ba}$, because $\mathrm{Ba}$ is extremely toxic (however, we believe barium hydroxide would probably have similar effect as strontium hydroxide). $\mathrm{Sr}(\mathrm{OH})_{2}$ has some issues with solubility at room temperature (it takes some stirring to dissolve it) but at higher temperature of the typical hydrothermal autoclave synthesis it has excellent solubility. $\operatorname{Sr}(\mathrm{II})$ has a charge of +2 , and it would require two proximal $\mathrm{AlO}_{4}^{-}$units to produce the resulting $\mathrm{Sr}(\mathrm{II})$-form zeolite compared with $1 \mathrm{AlO}_{4}^{-}$unit required to stabilize Na-form zeolite [3].

After synthesis, the resulting Sr/SSZ-13 and Na/SSZ-13 were centrifuged and washed with DI water multiple times. $\mathrm{NH}_{4}$-ion exchange was performed multiple times with ammonium nitrate to produce $\mathrm{NH}_{4}-$ forms of zeolite.

It is universally accepted that the measure of amount of Al pairs in zeolitic materials can be determined by $\mathrm{Co}(\mathrm{II})$ ion exchange capacity [37-41]. Co(II) ions are generally assumed to exist almost exclusively as $\mathrm{Co}(\mathrm{II}) / 2 \mathrm{Al}$ species in zeolites. We exchanged both $\mathrm{NH}_{4}-\mathrm{SSZ}-13$ samples with $\mathrm{Co}(\mathrm{II})$ ions under identical conditions and calcined in the air flow at $650{ }^{\circ} \mathrm{C}$. The resulting blue-powders with isolated $\mathrm{Co}(\mathrm{II})$ ions in distorted tetrahedral environment [42] on air slowly ( $\sim 5-7$ days) regain the pink color due to moisture adsorption and coordination of moisture to tetrahedral Co to form square-pyramidal and octahedral Co aqua complexes (Fig. S1) [42]. XANES characterization for both samples shows that Co is present in +2 oxidation state. XANES for the Co/ sample prepared from SSZ-13(Sr) showed better signal intensity than for the one prepared from SSZ-13(Na), already suggesting to us that Cobalt is present in higher amounts (Fig. S2) [samples were prepared with approx. similar masses of sample and similar pressed tablets]. With infra-red spectroscopy we looked at NO adsorption on Co/SSZ-13 material (Fig. 1A). NO adsorption produces two NO stretches that grow in concert upon NO titration. They belong to $\mathrm{Co}(\mathrm{II})(\mathrm{NO})_{2}$ complex [42-50] with symmetric NO stretch at $1900 \mathrm{~cm}^{-1}$ and asymmetric NO stretch at $1816 \mathrm{~cm}^{-1}$. This is typical for atomically-dispersed $\mathrm{Co}(\mathrm{II})$ ions in zeolite [42-50]. Co ions exist in extra-framework positions and not in silanol nests/silica matrix: the latter vibrate at slightly lower frequencies [42-50]. Importantly, 1 cobalt ion can adsorb up to $2 \mathrm{NO}$ molecules. $\mathrm{Co}(\mathrm{NO})_{2}$ complexes survive under vacuum at elevated temperature (Fig. 1b). This suggested to us Co/SSZ-13 materials would be useful for NO adsorption from ambient air. NO is a nuisance pollutant and Co-containing systems have previously shown promise for NO adsorption from ambient air. For these materials, it would be important to maximize the number of $\mathrm{Co}$ (II) ions per SSZ-13 mass: the amount of adsorbed cobalt correlates linearly with the number of Al pairs in SSZ-13 


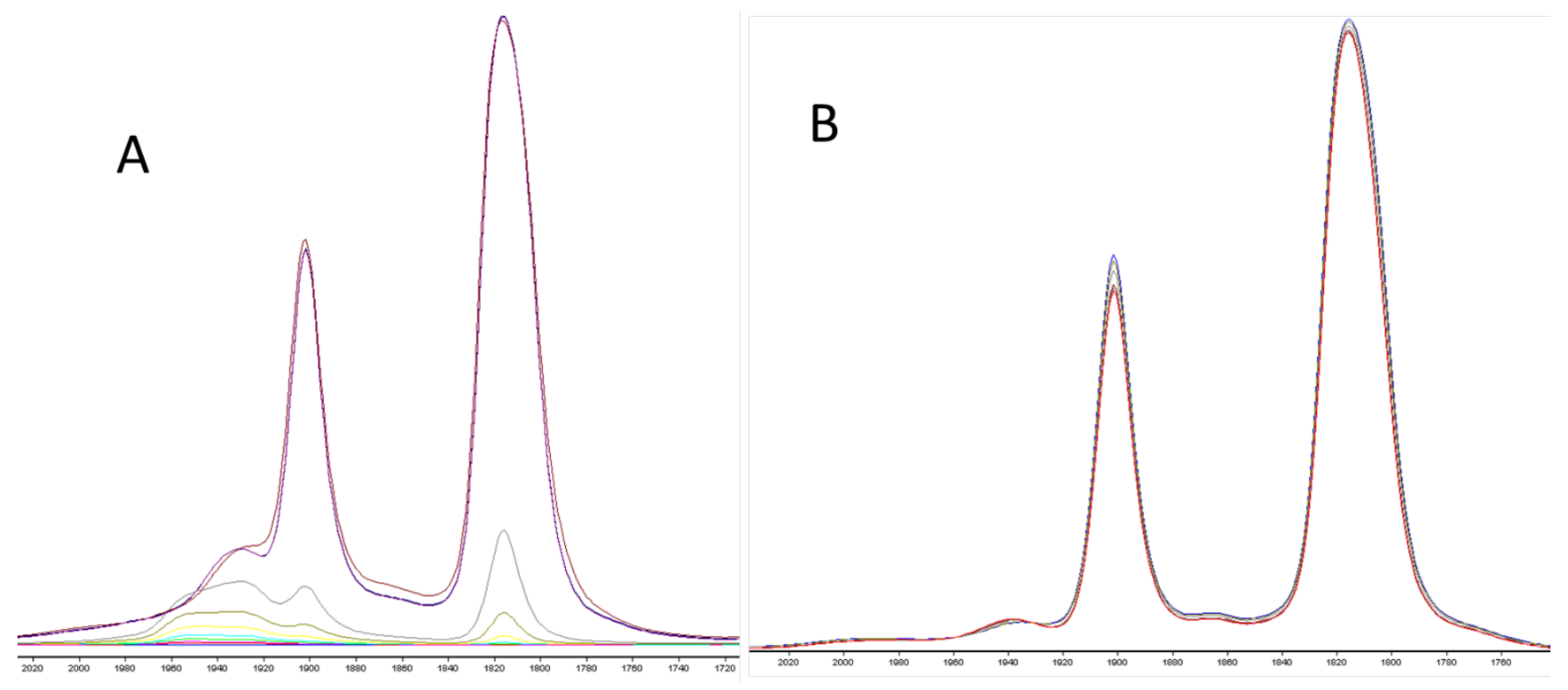

Figure 1. A. In-situ FTIR during NO adsorption ( 2 Torr) at room temperature on activated Co-SSZ-13. NO bands at 1900 and $1816 \mathrm{~cm}^{-1}$ belong to $\mathrm{Co}(\mathrm{II})(\mathrm{NO})_{2}$ complex. Minor band at $1930 \mathrm{~cm}^{-1}$ belongs to $\mathrm{NO}$ adsorbed on $\mathrm{Co}(\mathrm{III})$ ions of polynuclear cobalt oxide clusters. B. NO desorption from $\mathrm{Co}(\mathrm{II})(\mathrm{NO})_{2}$ under vacuum $\left(10^{-6}\right.$ Torr) at $80^{\circ} \mathrm{C}$. $\mathrm{Co}(\mathrm{II})(\mathrm{NO})_{2}$ complex shows resistance to decomposition.

material. Indeed, both Co/SSZ-13(Na) and Co-SSZ-13(Sr) are active for NO adsorption (Fig. 2). However, the material derived from Sr/SSZ-13 stores at least 55\% more NO compared with Co-SSZ-13(Na).

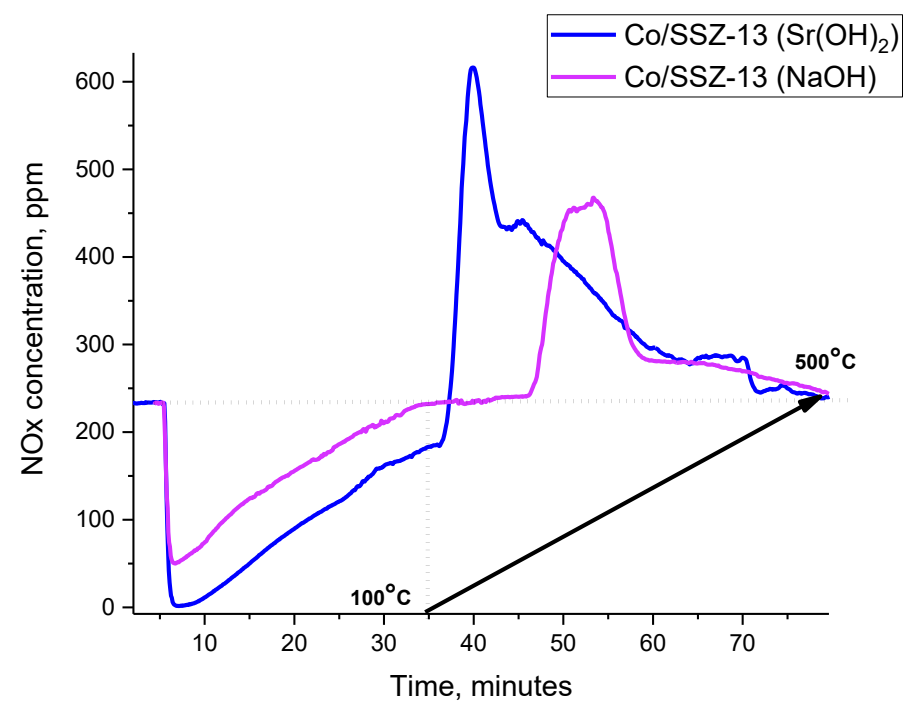

Figure 2. NOx adsorption on Co-SSZ-13 samples derived from $\mathrm{NaOH}$ and $\mathrm{Sr}(\mathrm{OH}) 2$ synthetic routes at $100{ }^{\circ} \mathrm{C}$ for $30 \mathrm{~min}($ after $5 \mathrm{~min}$ bypass) followed with TPD $\left(10^{\circ} \mathrm{C} / \mathrm{min}\right)$. The feed gas mixture contains $\sim 220 \mathrm{ppm}$ of $\mathrm{NOx}, 14 \% \mathrm{O}_{2}$ and $\sim 300 \mathrm{ppm} \mathrm{H}_{2} \mathrm{O}$. Sample mass $120 \mathrm{mg}$. Total flow rate $\sim 300 \mathrm{sscm} / \mathrm{min}$.

It is more advantageous for $\mathrm{NO}$ adsorption applications and it lasts long as a $\mathrm{NO}$ adsorber at ambient temperature from ambient air (Fig. 3). 


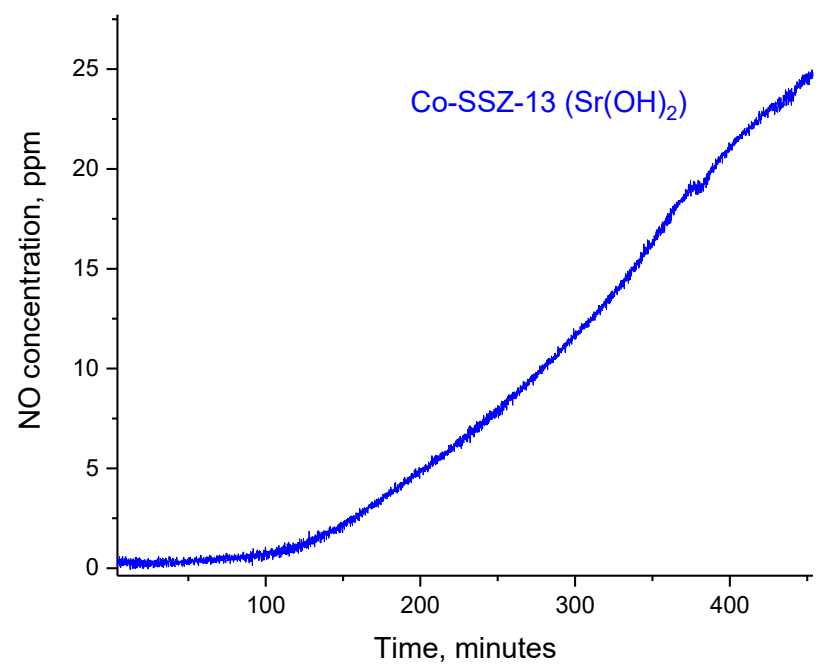

Figure 3. NOx adsorption on Co-SSZ-13 samples derived from $\mathrm{Sr}(\mathrm{OH})_{2}$ synthetic route at $23{ }^{\circ} \mathrm{C}$ while flowing gas mixture containing $\sim 27$ ppm of $\mathrm{NO}, 20 \% \mathrm{O}_{2}$ and $\sim 300 \mathrm{ppm} \mathrm{H}_{2} \mathrm{O}$ (adoption of $\mathrm{NO}$ from ambient air allows to keep NO level below 2 ppm for 160 minutes). Sample mass $120 \mathrm{mg}$. Total flow rate $300 \mathrm{sscm} / \mathrm{min}$.

The higher number of $\mathrm{Al}$ pairs is the direct consequence of $\mathrm{Sr}(\mathrm{OH})_{2}$ use during SSZ-13 synthesis. We also tested this material as a PNA material for vehicle exhaust. Despite its ability to absorb NOx during vehicle cold start, $\mathrm{Co} / \mathrm{SSZ}-13$ is not viable for $\mathrm{NO}_{\mathrm{x}}$ adsorber applications because it releases $\mathrm{NO}_{\mathrm{x}}$ too early (Fig.4).

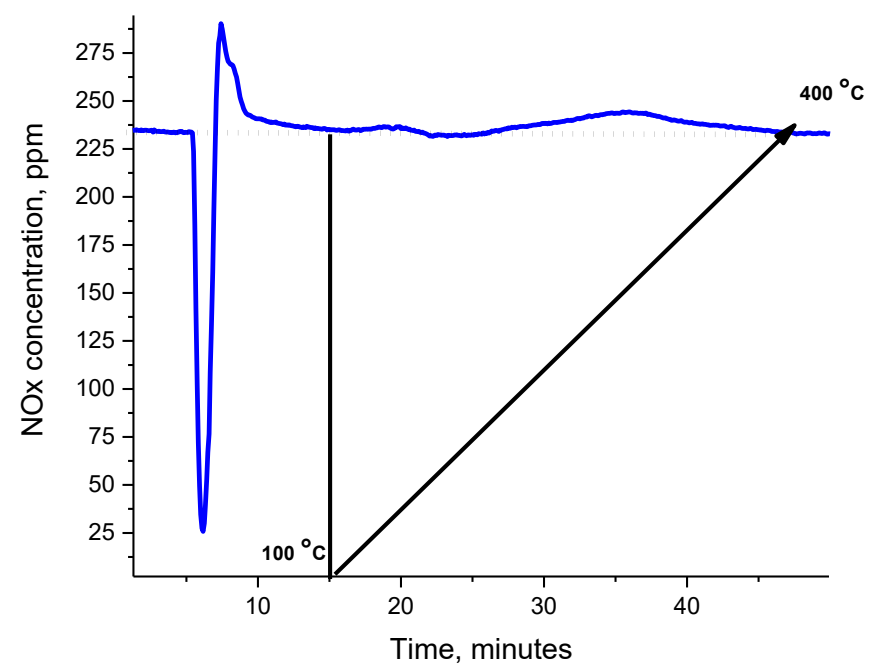

Figure 4. NOx adsorption on Co-SSZ-13 samples derived from $\mathrm{Sr}(\mathrm{OH}) 2$ synthetic route at $100{ }^{\circ} \mathrm{C}$ for 30 min (after 5 min bypass) followed with TPD $\left(10^{\circ} \mathrm{C} / \mathrm{min}\right)$. The feed gas mixture contains $\sim 220 \mathrm{ppm}$ of NOx, $200 \mathrm{ppm} \mathrm{CO}, 14 \% \mathrm{O}_{2}$ and $\sim 3 \% \mathrm{H}_{2} \mathrm{O}$. Sample mass $120 \mathrm{mg}$. Total flow rate $\sim 300 \mathrm{sscm} / \mathrm{min}$. 
However, it is important to note that presence of Co ions is not detrimental for NO storage (unlike for Nacontaining materials, for example as outlined in our previous study [25]). The presence of higher fraction of paired Al sites in Co/SSZ-13(Sr) compared with Co-SSZ-13(Na) prompted us to investigate whether this sample possesses higher hydrothermal stability. Remarkably, even though HT aging Co-SSZ-13(Na) at $850{ }^{\circ} \mathrm{C}$ almost completely destroys its NO storage capacity, hydrothermal aging of Co-SSZ-13(Sr) at at $850{ }^{\circ} \mathrm{C}$ and then further $900{ }^{\circ} \mathrm{C}$ preserves its NO storage capacity/uptake (Fig. 5).

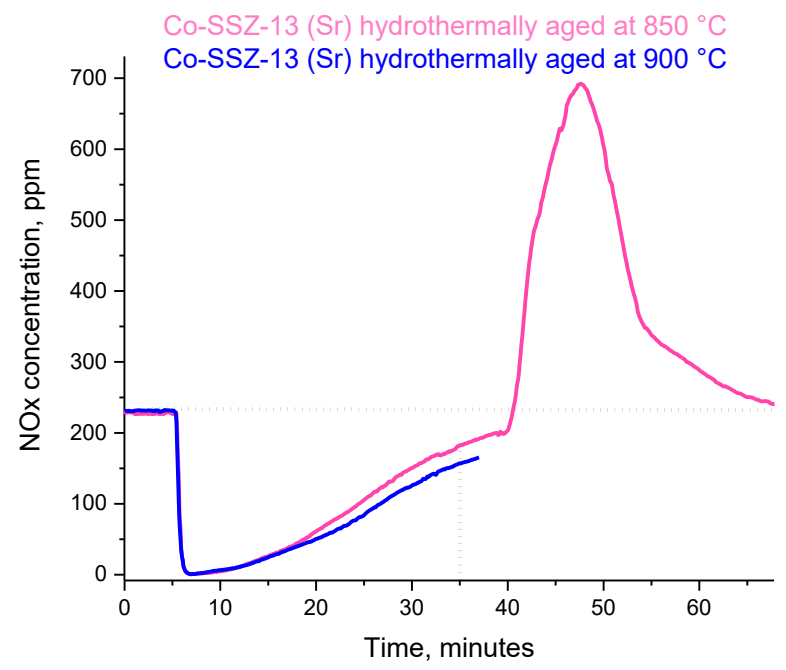

Figure 5. NOx adsorption on Co-SSZ-13 sample derived from $\mathrm{Sr}(\mathrm{OH})_{2}$ synthetic route at $100{ }^{\circ} \mathrm{C}$ for 30 min (after 5 min bypass) followed with TPD $\left(10^{\circ} \mathrm{C} / \mathrm{min}\right)$. The feed gas mixture contains $\sim 220 \mathrm{ppm}$ of $\mathrm{NOx}, 14 \% \mathrm{O}_{2}$ and $\sim 300 \mathrm{ppm} \mathrm{H}_{2} \mathrm{O}$. Sample mass $120 \mathrm{mg}$. Total flow rate $\sim 300 \mathrm{sscm} / \mathrm{min}$. The sample was first hydrothermally aged at $850^{\circ} \mathrm{C}$ and tested for PNA. Then it was further hydrothermally aged at $900{ }^{\circ} \mathrm{C}$ and PNA adsorption capacity was recorded at $100{ }^{\circ} \mathrm{C}$ for 30 minutes (after 5 minute bypass).

It means, that hydrothermal aging of this material at $900{ }^{\circ} \mathrm{C}$ does not lead to Cobalt(II) ion removal from the framework or collapse of SSZ-13 zeolitic structure. This, to the best of our knowledge, is the first demonstration of metal-promoted SSZ-13 hydrothermal stability at temperatures as high as $900{ }^{\circ} \mathrm{C}$. This corroborates our intuitive suggestion that distribution of Al sites within zeolite framework is a key factor in zeolitic hydrothermal stability: the material with higher number of Al pairs (synthesized in the presence of alkaline earth metal hydroxide in the synthesis gel) shows much higher hydrothermal stability than its SSZ-13(Na) analogue. This remarkable property of Co/SSZ-13(Sr) material, thus, prompted us to load $1.7 \mathrm{wt} \% \mathrm{Pd}$ in its micropores and study its PNA properties and hydrothermal stability of the resulting Pdcontaining SSZ-13 composite [19-35]. Indeed, the sample shows excellent PNA performance after loading Pd in it (Fig. 6). 


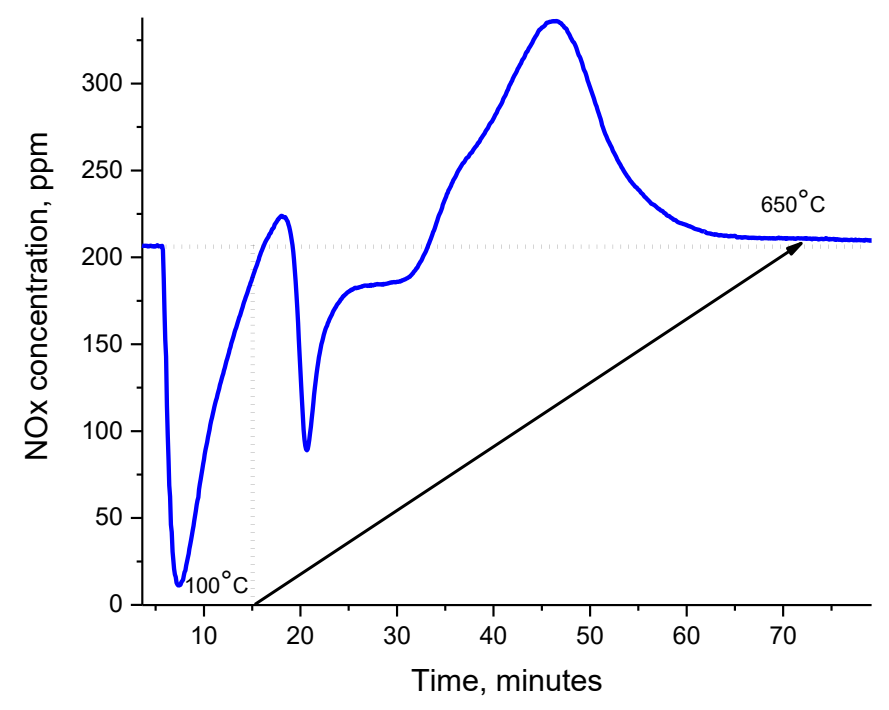

Figure 6. NOx adsorption on "fresh" $1.7 \mathrm{wt} \% \mathrm{Pd} / \mathrm{Co}-\mathrm{SSZ}-13$ sample derived from $\mathrm{Sr}(\mathrm{OH})_{2}$ synthetic route at $100{ }^{\circ} \mathrm{C}$ for $30 \mathrm{~min}($ after $5 \mathrm{~min}$ bypass) followed with TPD $\left(10{ }^{\circ} \mathrm{C} / \mathrm{min}\right)$. The feed gas mixture contains $\sim 220 \mathrm{ppm}$ of NOx, $\sim 250 \mathrm{ppm} \mathrm{CO}, 14 \% \mathrm{O}_{2}$ and $\sim 3 \% \mathrm{H}_{2} \mathrm{O}$. Sample mass $120 \mathrm{mg}$. Total flow rate $\sim 300 \mathrm{sscm} / \mathrm{min}$.

The second NOx adsorption peak occurs during PNA on fresh Pd-Co-SSZ-13(Sr) sample at higher temperatures (that adsorption peak is absent for just Pd-SSZ-13 materials [20-23,25,27,28]). We thus attribute it to the presence of Co in the "fresh" sample. Previously, the best known Pd-zeolitic PNA materials could survive prolonged hydrothermal aging of $800-820^{\circ} \mathrm{C}$. However, at higher temperatures they lost most of their performance (see, for example, our Pd-SSZ-39 and Pd/FER studies [27,33]). We first hydrothermally aged novel $1.7 \mathrm{wt} \%$ Pd-Co-SSZ-13 material at $850{ }^{\circ} \mathrm{C}$ for 10 hours in air/steam flow. Surprisingly, the low-temperature NOx adsorption band associated with Pd was fully preserved, and the sample was active as a PNA material (Fig. 7). Encouraged by this unprecedented result (no SSZ-13 material have been previously demonstrated to have such high hydrothermal stability), we further aged this material (after it was already aged at $850^{\circ} \mathrm{C}$ ) for the same duration in air/steam flow at $900{ }^{\circ} \mathrm{C}$. To our delight, its PNA performance did not deteriorate (Fig. 7). 


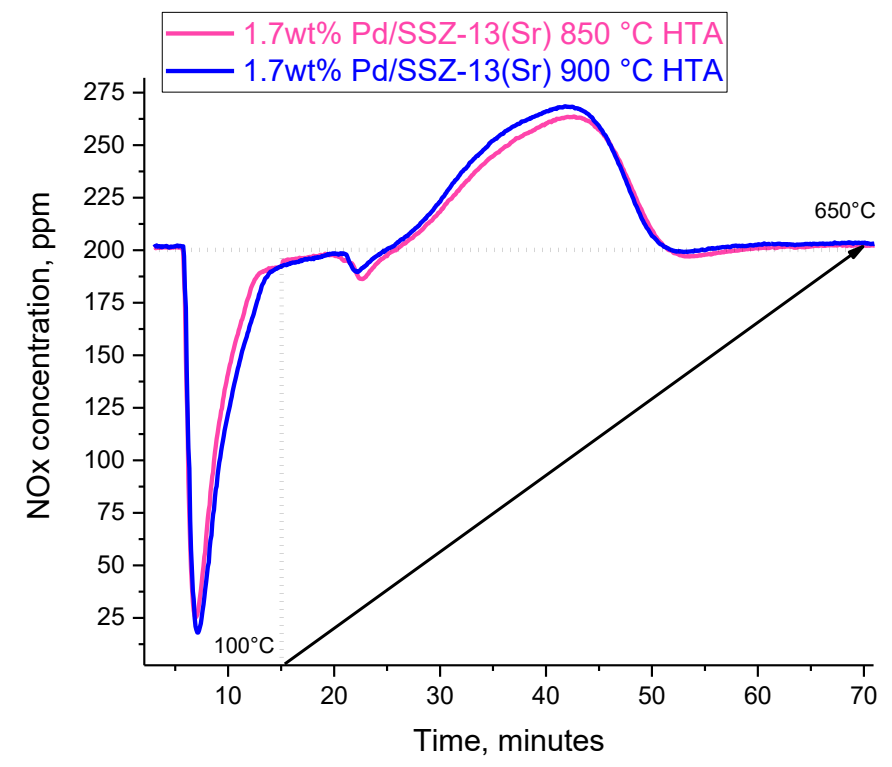

Figure 7. NOx adsorption on 850 and $900{ }^{\circ} \mathrm{C}$ hydrothermally aged $1.7 \mathrm{wt} \% \mathrm{Pd} / \mathrm{Co}-\mathrm{SSZ}-13$ sample derived from $\mathrm{Sr}(\mathrm{OH})_{2}$ synthetic route at $100{ }^{\circ} \mathrm{C}$ for $30 \mathrm{~min}$ (after $5 \mathrm{~min}$ bypass) followed with $\mathrm{TPD}\left(10^{\circ} \mathrm{C} / \mathrm{min}\right)$. The feed gas mixture contains $\sim 220 \mathrm{ppm}$ of $\mathrm{NOx}, \sim 250 \mathrm{ppm} \mathrm{CO}$, $14 \% \mathrm{O}_{2}$ and $\sim 3 \% \mathrm{H}_{2} \mathrm{O}$. Sample mass $120 \mathrm{mg}$. Total flow rate $\sim 300 \mathrm{sscm} / \mathrm{min}$.

This is the most hydrothermally stable known PNA material ever reported. When we further hydrothermally aged this material (after it was aged at first at $850^{\circ} \mathrm{C}$ and then at $900{ }^{\circ} \mathrm{C}$ ) at $930^{\circ} \mathrm{C}$ for 10 hours in air/steam flow, 55\% of PNA capacity was lost - still, some substantial PNA capacity was preserved and even such extremely harsh hydrothermal treatment did not lead to full collapse of the zeolitic material (Fig. 8).

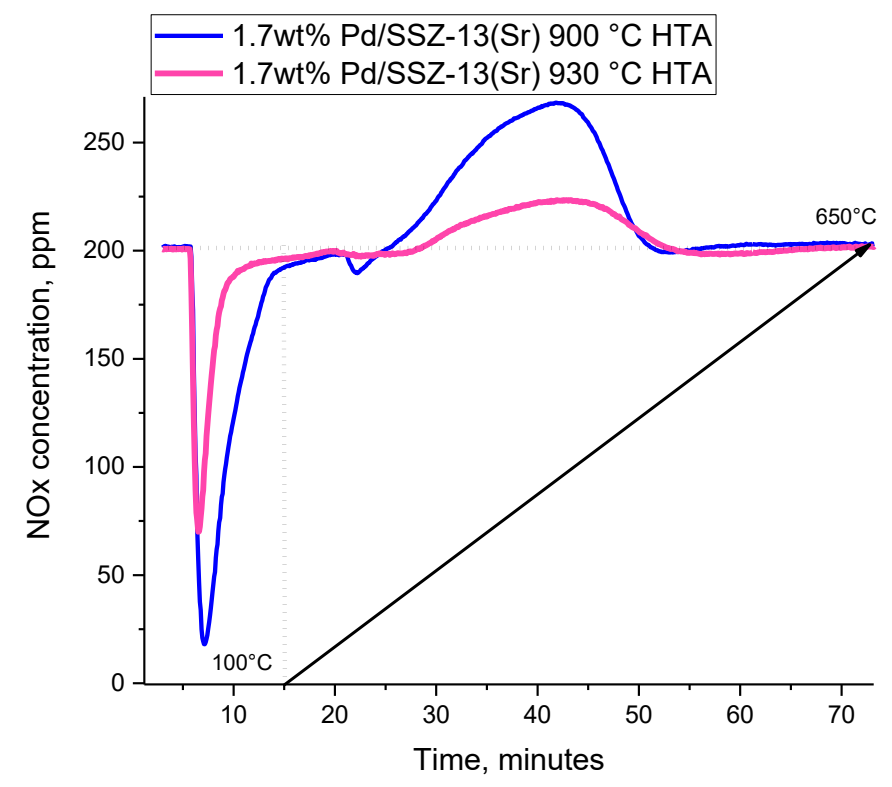

Figure 8. NOx adsorption on 900 and $930{ }^{\circ} \mathrm{C}$ hydrothermally aged $1.7 \mathrm{wt} \% \mathrm{Pd} / \mathrm{Co}-\mathrm{SSZ}-13$ sample derived from $\mathrm{Sr}(\mathrm{OH})_{2}$ synthetic route at $100{ }^{\circ} \mathrm{C}$ for $30 \mathrm{~min}$ (after $5 \mathrm{~min}$ bypass) followed with TPD $\left(10^{\circ} \mathrm{C} / \mathrm{min}\right)$. The feed gas mixture contains $\sim 220 \mathrm{ppm}$ of NOx, $\sim 250 \mathrm{ppm} \mathrm{CO}$, $14 \% \mathrm{O}_{2}$ and $\sim 3 \% \mathrm{H}_{2} \mathrm{O}$. Sample mass $120 \mathrm{mg}$. Total flow rate $\sim 300 \mathrm{sscm} / \mathrm{min}$. 
In summary, we report a simple and scalable method of increasing Al pairs distribution in siliceous SSZ13 ( $\mathrm{Si} / \mathrm{Al}$ ratio at least 10$)$. We show that this distribution is key in exchanging higher amounts of divalent metal cations (Co(II) and Pd(II), for example) atomically dispersed in the SSZ-13 micropores. The resulting materials have higher adsorption capacity for NO under different conditions. Furthermore, we show remarkable hydrothermal stability of the resulting metal zeolite materials that survive extraordinarily harsh hydrothermal aging conditions (encountered in vehicle exhaust under certain circumstances) at 900 ${ }^{\circ} \mathrm{C}$ and that do not lose full NOx adsorption capacity at even higher temperatures $\left(930{ }^{\circ} \mathrm{C}\right)$. Our study opens up a pathway to prepare new zeolite and divalent metal-zeolite composites/catalysts with (hydro)thermal robustness not available before.

\section{References}

(1) Beale, A. M.; Gao, F.; Lezcano-Gonzalez, I.; Peden, C. H. F.; Szanyi, J. Chem. Soc. Rev. 2015, 44, 7371-7405.

(2) Liu, L., Corma, A. Nat Rev Mater (2020). https://doi.org/10.1038/s41578-020-00250-3

(3) Zones, S.I. US Pat 4544 538, 1985.

(4) J.-H. Kwak, R. G. Tonkyn, D. H. Kim, J. Szanyi, C. H. Peden, J. Catal., 2010, 275, 187-190.

(5) I. Bull, A. Moini, G. Koermer, J. Patchett, W. Jaglowski, S. Roth, US Patent US20070134146A1, 2010.

(6) DW Fickel, RF Lobo, J. Phys. Chem. C 2010, 114 (3), 1633-1640.

(7) J.H. Kwak, D. Tran, S.D. Burton, J. Szanyi, J.H. Lee, C.H.F. Peden J. Catal., 287 (2012), p. 203.

(8) Royal College of Paediatrics and Child Health. Every breath we take-the lifelong impact of air pollution. London: Royal College of Paediatrics and Child Health, 2016.

(9) Sachtler W.M.H. (2002) Catalysis from Art to Science. In: Carley A.F., Davies P.R., Hutchings G.J., Spencer M.S. (eds) Surface Chemistry and Catalysis. Fundamental and Applied Catalysis. Springer, Boston, MA

(10)Khair, M. K.; Majewski, W. A. Diesel emissions and their control; SAE International, Warrendale, 2006.

(11)T. Seiyama, T. Arakawa, T. Matsuda, N. Yamazoe, and Y. Takita, Chem. Lett., 781 (1975)

(12)J.H. Kwak, D. Tran, J. Szanyi, C.H.F. Peden, J.H. Lee, Catal. Lett., 142 (2012), p. 295.

(13)ST Korhonen, DW Fickel, RF Lobo, BM Weckhuysen, AM Beale, Chemical Communications 47 (2), 800-802

(14)Negri, C.; Selleri, T.; Borfecchia, E.; Martini, A.; Lomachenko, K. A.; Janssens, T. V.W.; Cutini, M.; Bordiga, S.; Berlier, G. J. Am. Chem. Soc. 2020, 142, 15884-15896.

(15)J. H. Kwak, T. Varga, C. H. F. Peden, F. Gao, J. C. Hanson and J. Szanyi, J. Catal., 2014, 314, 83-93.

(16)Gao, F.; Mei, D. H.; Wang, Y. L.; Szanyi, J.; Peden, C. H. F. J. Am. Chem. Soc. 2017, 139, 4935-4942.

(17)Gao, F.; Walter, E. D.; Kollar, M.; Wang, Y.; Szanyi, J.; Peden, C. H. F. J. Catal. 2014, 319, 1-14.

(18) K. Khivantsev, J.-H. Kwak, N. R. Jaegers, J. Szanyi, Chemrxiv, 2020 DOI: 10.26434/chemrxiv.13134770

(19)Chen, H.-Y.; Collier, J. E.; Liu, D.; Mantarosie, L.; Durán- Martín, D.; Novák, V.; Rajaram, R. R.; Thompsett, D. Catal. Lett. 2016, 146 (9), 1706-1711.

(20)Khivantsev, K.; Jaegers, N. R.; Kovarik, L.; Hanson, J. C.; Tao, F. (Feng); Tang, Y.; Zhang, X.; Koleva, I. Z.; Aleksandrov, H. A.; Vayssilov, G. N.; Wang, Y.; Gao, F.; Szanyi, J. Angew. Chem. 2018, 130 (51), 16914-16919.

(21)Khivantsev, K.; Jaegers, N. R.; Kovarik, L.; Prodinger, S.; Derewinski, M. A.; Wang, Y.; Gao, F.; Szanyi, J. Appl. Catal. A. Gen. 2019, 569, 141-148.

(22)Khivantsev, K.; Jaegers, N. R.; Koleva, I. Z.; Aleksandrov, H. A.; Kovarik, L.; Engelhard, M.; Gao, F.; Wang, Y.; Vayssilov, G. N.; Szanyi, J. J. Phys. Chem. C 2020, 124 (1), 309-321.

(23)Khivantsev, K.; Gao, F.; Kovarik, L.; Wang, Y.; Szanyi, J. J. Phys. Chem. C 2018, 122 (20), 10820-10827.

(24)Moliner, M.; Corma, A. React. Chem. Eng. 2019, 4 (2), 223-234.

(25)Khivantsev, K.; Jaegers, N. R.; Kovarik, L.; Hu, J. Z.; Gao, F.; Wang, Y.; Szanyi, J. Emiss. Control Sci. Technol. 2019. DOI: 10.1007/s40825-019-00139-w 
(26)E. Bello, V. J. Margarit, E. M. Gallego, F. Schuetze, C. Hengst , A. Corma, M. Moliner, Microporous and Mesoporous Materials 302 (2020) 110222.

(27)K. Khivantsev, N.R. Jaegers, L. Kovarik, M. Wang, J.Z. Hu, Y. Wang, M.A. Derewinski, J. Szanyi, Appl. Catal. B. 2021, 280,119449

(28)K Khivantsev, J Szanyi, NR Jaegers, L Kovarik, F Gao, Y Wang, US Patent App. 16/546,641

(29)Ryou, Y. S.; Lee, J.; Cho, S. J.; Lee, H.; Kim, C. H.; Kim, D. Appl. Catal. B Environ. 2017, 212, 140-149.

(30)Ryou, Y. S.; Lee, J.; Lee, H.; Kim, C. H.; Kim, D. H., Catal. Today 2019, 320, 175-180.

(31)Lee, J.; Ryou, Y.; Hwang, S.; Kim, Y.; Cho, S. J.; Lee, H.; Kim, C. H.; Kim, D. H., Catal. Sci. Technol. 2019,9 (1), $163-173$.

(32)Kim, Y.; Hwang, S.; Lee, J.; Ryou, Y. S.; Lee, H.; Kim, C. H.; Kim, D. H. Emiss. Control Sci. Technol. 2019,5 (2), $172-182$.

(33)K. Khivantsev, X. Wei, L. Kovarik, N. R. Jaegers, E. D. Waler, P. Tran, Y. Wang, J. Szanyi, Chemrxiv 2020 D0I: 10.26434/chemrxiv.12385577

(34)H Zhao, X Chen, A Bhat, Y Li, JW Schwank, Applied Catalysis B: Environmental 2021, 282, 119611,

(35)H Zhao, X Chen, A Bhat, Y Li, JW Schwank, Applied Catalysis B: Environmental, 2021, 286, 119874.

(36)Dedecek, J.; Sobalík, Z.; Wichterlova , B. Catal. Rev.: Sci. Eng. 2012, 54, 135-223.

(37)Pashkova, V.; Klein, P.; Dedecek, J.; Tokarova, V.; Wichterlova, B. Microporous Mesoporous Mater. 2015, 202, 138-146.

(38) Gabova, V.; Dedecek, J.; Cejka, J. Chem. Commun. 2003, 1196-1197.

(39)Dedecek, J.; Balgova, V.; Pashkova, V.; Klein, P.; Wichterlova, B., Chem. Mater. 2012, 24, 3231-3239.

(40)Burton, A. W.; Zones, S. I. Stud. Surf. Sci. Catal. 2007, 168, 137-179.

(41) Lobo, R. F.; Zones, S. I.; Davis, J. Inclus. Phenom. Mol. 1995, 21, 47-78.

(42) K. Khivantsev, et. al. ChemCatChem, 2019, 10, 736-742.

(43) K.Hadjiivanov, E.Ivanova, M.Daturi, J.Saussey, J.-C.Lavalley, Chem. Phys. Lett. 2003, 370, 712-718.

(44) A. Mihaylova, K. Hadjiivanov, M. Che, J. Phys. Chem. B 2006, 110, 39, 19530-19536.

(45)Hadjiivanov, K. I., Catal. Rev. Sci. Eng. 2000, 42, 71-144.

(46)Hadjiivanov, K.; Saussey, J.; Freysz, J. L.; Lavalley, J. C., Catal. Lett. 1998, 52, 103-108.

(47) B. Tsyntsarski, V. Avreyska, H. Kolev, Ts. Marinova, D. Klissurski, K. Hadjiivanov, J. Mol. Catal. A: Chem. 193 (2003) 139-149.

(48) J. H. Lunsford, P. J. Hutta, M. J. Lin, and K. A. Windhorst, Inorg. Chem. 1978, 17, 3, 606-610.

(49) K. A. Windhorst, J. H. Lunsford, J. Am. Chem. Soc. 1975, 97, 6, 1407-1412.

(50) K. Chakarova, K. Hadjiivanov, Microporous and Mesoporous Materials 123 (2009) 123-128.

Competing interests: Authors have no conflicts to declare.

\section{Acknowledgements}

We would like to thank the financial support by Crosscut Lean Exhaust Emissions Reduction Simulations (CLEERS), which is an initiative funded by the U.S. Department of Energy (DOE) Vehicle Technologies Office to support the development of accurate tools for use in the design, calibration, and control of next generation engine/emissions control systems that maximize efficiency while complying with emissions regulations. M.A.D. was supported by the Materials Synthesis and Simulation Across Scales (MS3) Initiative conducted under the Laboratory Directed Research \& Development Program at PNNL. Most experiments were conducted in the Environmental Molecular Sciences Laboratory (EMSL), a national scientific user facility sponsored by the Department of Energy's Office of Biological and Environmental Research at Pacific Northwest National Laboratory (PNNL). PNNL is a multi-program national laboratory operated for the DOE by Battelle Memorial Institute under Contract DE-AC06- 76RL01830. 


\section{Supplementary Information}

\section{Controlling Al-pair abundance in SSZ-13 zeolite via alkaline-earth metal assisted synthesis produces hydrothermally stable and active Co and Pd-SSZ-13 materials for pollutant abatement applications}

Konstantin Khivantsev ${ }^{1 *} \uparrow$, Miroslaw A. Derewinski ${ }^{1,2^{*}} \uparrow$, Nicholas R. Jaegers ${ }^{1}$, Daria Boglaienko ${ }^{1}$, Xavier Isidro Pereira Hernandez ${ }^{1}$, Carolyn Pearce ${ }^{1}$, Yong Wang ${ }^{1,3}$ and Janos Szanyi ${ }^{1 *} \dagger$

${ }^{1}$ Pacific Northwest National Laboratory Richland, WA 99352 USA

${ }^{2}$ J. Haber Institute of Catalysis and Surface Chemistry, Polish Academy of Sciences, Krakow 30-239, Poland

${ }^{3}$ The Gene and Linda Voiland School of Chemical Engineering and Bioengineering, Washington State University

Pullman, WA 99164-6515

* corresponding authors: MAD, KK, JSz

†these authors contributed equally: KK, MAD, JSz

$\mathrm{Na} / \mathrm{SSZ}-13$ zeolite with $\mathrm{Si} / \mathrm{Al} 10$ was hydrothermally synthesized using the following recipe: $0.8 \mathrm{~g}$ of $\mathrm{NaOH}$ (Sigma Aldrich) was dissolved in $50 \mathrm{ml}$ of deionized water. Then, $17 \mathrm{~g}$ of TMAda-OH (Sachem Inc., 25\% N,N,N-trimethyl-1-adamantyl ammonium hydroxide) was added as a structure directing agent. Consequently, $0.75 \mathrm{~g}$ of $\mathrm{Al}(\mathrm{OH})_{3}$ (Sigma Aldrich, $\sim 54 \% \mathrm{Al}_{2} \mathrm{O}_{3}$ ) was slowly added to the solution and stirred at $400 \mathrm{rpm}$ until it was completely dissolved. Afterwards, $20.0 \mathrm{~g}$ of LUDOX HS-30 colloidal silica (Sigma Aldrich, $30 \mathrm{wt} \%$ suspension in $\mathrm{H}_{2} \mathrm{O}$ ) was added slowly to the solution until gel was formed.

The obtained gel was sealed in a $125 \mathrm{~mL}$ Teflon-lined stainless steel autoclave containing a magnetic stir bar. Hydrothermal synthesis was carried out at $160{ }^{\circ} \mathrm{C}$ under continuous gel stirring at $400 \mathrm{rpm}$ for 4 days. After synthesis, the zeolite cake was separated from the suspension by centrifugation and washed three times with deionized water. It was then dried at $80{ }^{\circ} \mathrm{C}$ under $\mathrm{N}_{2}$ flow overnight and calcined in air at $550{ }^{\circ} \mathrm{C}$ for $5 \mathrm{~h}$ in order to remove the SDA. $\mathrm{NH}_{4} / \mathrm{SSZ}-13$ was obtained by ion exchange of the asprepared Na/SSZ-13 zeolite with $1 \mathrm{M}$ ammonium nitrate solution solution at $80{ }^{\circ} \mathrm{C}$ for $5 \mathrm{~h}$. The process was repeated two times.

Hydrothermal synthesis of $\mathrm{Sr} / \mathrm{SSZ}-13$ with $\mathrm{Si} / \mathrm{Al} \sim 10$ in the presence of $\mathrm{Sr}(\mathrm{OH})_{2}$ was performed using similar recipe as for the Na/SSZ-13. However, in this case mole-equivalent amount of strontium hydroxide octahydrate (Sigma Aldrich) was used instead of $\mathrm{NaOH}$. After synthesis, the zeolite cake was separated from the suspension by centrifugation and washed multiple times with deionized water. It was then dried at $80{ }^{\circ} \mathrm{C}$ under $\mathrm{N}_{2}$ flow overnight and calcined in air at $550^{\circ} \mathrm{C}$ for $5 \mathrm{~h}$ in order to remove the SDA. 
$\mathrm{NH}_{4} / \mathrm{SSZ}-13$ was obtained by ion exchange of the as-prepared Sr/SSZ-13 zeolite with $1 \mathrm{M}$ ammonium nitrate solution solution at $80^{\circ} \mathrm{C}$ for $5 \mathrm{~h}$. The process was repeated five times.

Cobalt(II) ion-exchange was performed by dispersing $1 \mathrm{~g}$ of $\mathrm{NH}_{4}-\mathrm{SSZ}-13(\mathrm{Na})$ and $\mathrm{NH}_{4}-\mathrm{SSZ}-13(\mathrm{Sr})$ powders in excess $(150 \mathrm{ml}) 2 \mathrm{M}$ cobalt(II) nitrate (Sigma-aldrich) solution at $80{ }^{\circ} \mathrm{C}$ with continuous stirring for 8 hours. Then, the powder was separated by centrifugation and washed with excess DI water 3 times (with centrifugation after each wash), dried at $80{ }^{\circ} \mathrm{C}$ in air flow and subsequently calcined at $650{ }^{\circ} \mathrm{C}$ for 4 hours.

Palladium tetramine nitrate (10\% solution in water, Sigma-aldrich) was used to load $1.7 \mathrm{wt} \% \mathrm{Pd}$ in Co-SSZ-13. More specifically, desired amount of palladium precursor solution was mixed with minimum amount of water (the total volume approximately equivalent to the pore volume of zeolite $\sim 0.25 \mathrm{ml} / \mathrm{g}$ ), then added drop-wise with a micropipette to Co-SSZ-13 powder.

Standard NOx adsorption tests were conducted in a plug-flow reactor system with powder samples (120 mg, 60-80 mesh) loaded in a quartz tube, using a synthetic gas mixture that contained $\sim 200-220$ or 27 ppm of $\mathrm{NO}, 250 \mathrm{ppm}$ or $0 \mathrm{CO}, 300 \mathrm{ppm}$ or $3 \% \mathrm{H}_{2} \mathrm{O}, 14 \%$ or $20 \% \mathrm{O}_{2}$ ) balanced with $\mathrm{N}_{2}$ at a flow rate of $300 \mathrm{sscm}$.

All the gas lines were heated to over $100{ }^{\circ} \mathrm{C}$. Concentrations of reactants and products were measured by an online MKS MultiGas 2030 FTIR gas analyzer with a gas cell maintained at $191^{\circ} \mathrm{C}$. Two four-way valves were used for gas switching between the reactor and the bypass. Prior to storage testing at $100{ }^{\circ} \mathrm{C}$, the sample was pretreated in air flow for $1 \mathrm{~h}$ at $550{ }^{\circ} \mathrm{C}$ and cooled to the target temperature in the same feed. The gas mixture was then switched from the reactor to the bypass, and desired concentration of NOx was added to the mixture. Upon stabilization, the gas mixture was switched back from bypass to the reactor for storage testing for $10 \mathrm{~min}$. The sample was then heated to $650{ }^{\circ} \mathrm{C}$ at a rate of $10{ }^{\circ} \mathrm{C} / \mathrm{min}$ to record the desorption profiles of gases in the effluent. Ambient-temperature measurements were performed with $120 \mathrm{mg}$ of sample at $23^{\circ} \mathrm{C}$ by flowing $27 \mathrm{ppm} \mathrm{NO}$ (with $20 \%$ oxygen, 300 ppm water balanced in nitrogen) at $300 \mathrm{sscm} / \mathrm{min}$ rate at constant temperature.

XANES experiments on Co/SSZ-13 samples were performed on bench-top easyXAFS instrument. Details about the instrument can be found elsewhere (reference: Seidler, G T; Mortensen, D R; Remesnik, A J; Pacold, J I; Ball, N A; Barry, N; Styczinski, M; Hoidn, O R. Review of scientific instruments online. , 2014, Vol.85(11), p.113906 ISSN: 0034-6748 , 1089-7623; DOI: 10.1063/1.4901599; PMID: 25430123). Approximately $150 \mathrm{mg}$ of Co-SSZ-13 was pressed into a circular tablet with a press to give 
tablet with sufficient thickness to provide enough E-jump during measurements. The Co-SSZ-13(Sr) saple had higher amount of Co which allowed us to collect high-quality XANES data with edge step of 0.54. Energy edge was calibrated using Co foil standard (comparing Co foil lab data with Co foil synchrotron data and accounting for the slight shift in energy).

The in situ static transmission IR experiments were conducted in a home-built cell housed in the sample compartment of a Bruker Vertex 80 spectrometer, equipped with an MCT detector and operated at 4 $\mathrm{cm}^{-1}$ resolution. The powder sample was pressed onto a tungsten mesh which, in turn, was mounted onto a copper heating assembly attached to a ceramic feedthrough. The sample could be resistively heated, and the sample temperature was monitored by a thermocouple spot welded onto the top center of the W grid. NO was cleaned with multiple freeze-pump-thaw cycles. Prior to spectrum collection, a background with the activated (annealed at $300{ }^{\circ} \mathrm{C}$ ) sample in the IR beam was collected. Each spectrum reported is obtained by averaging 256 scans. 
A

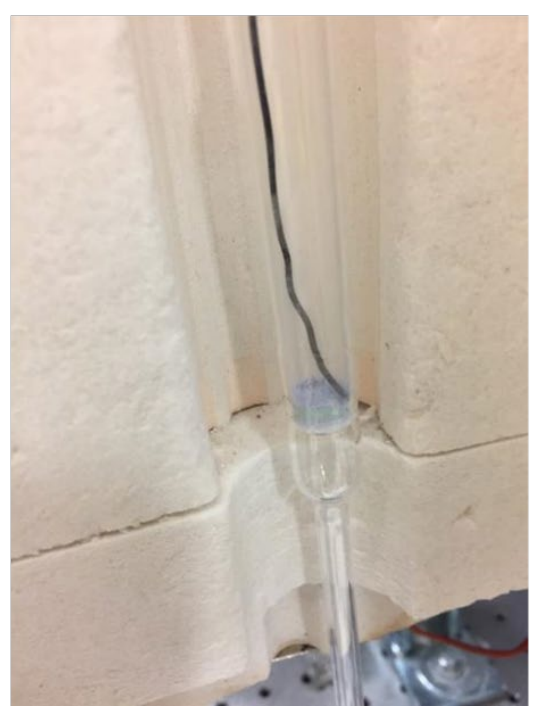

B

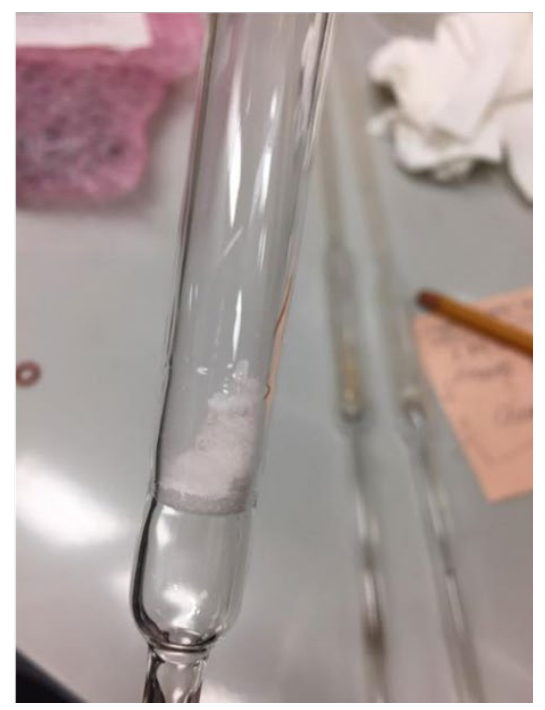

Fig. S1. A. Dehydrated Co-SSZ-13(Na) sample. Blue colour is due to presence of Co(II) cations in distorted tetrahedral ligand environment. B. The same sample exposed to ambient air for $\sim 7$ Days. This sample slowly adsorbs moisture from ambient air forming pink-ish Co(II)/SSZ-13 with hydrated octahedral (or square-pyramidal) Co(II) cations.
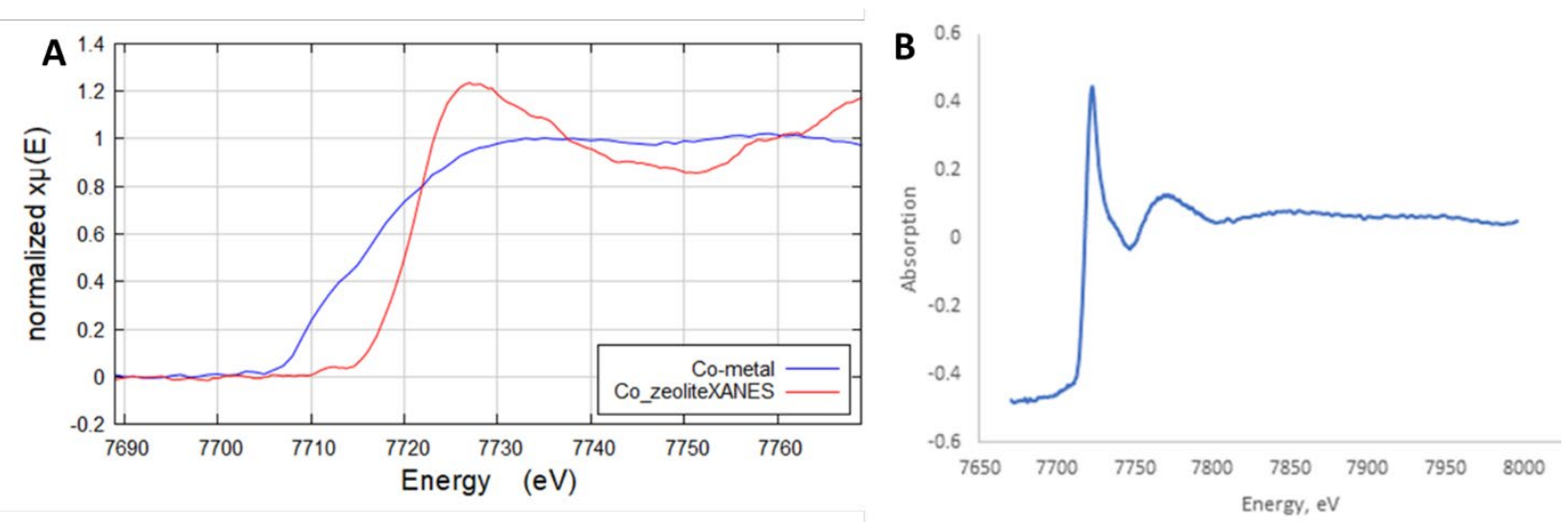

Fig. S2. A. Co K-edge XANES spectrum for Co-SSZ-13(Na) sample. Comparison with Co-metal foil is provided. B. Co K-edge XANES spectrum for Co-SSR-13(Sr). 